\title{
Johns-Manville Products Corp. $v$. Superior Court: Intentional Aggravation of Injury as an Exception to Exclusive Workers' Compensation Remedies
}

In Johns-Manville Products Corp. v. Superior Court, ${ }^{1}$ the California Supreme Court held that an employee can recover damages from his employer in a coinmon law tort action for fraudulently concealed injuries that aggravate initial, nonactionable injuries. ${ }^{2}$ Johns-Manville Products is a landmark decision in two respects. The California Supreme Court held for the first tine that workers' coinpensation is not the exclusive remedy for all injuries sustained in the actual course of employinent. An employee may inaintain an action in tort-and may pray for both general and punitive damages-for injuries resulting from certain egregious employer misconduct. Furthermore, the decision inarks the first tine that any California appellate court has allowed a tort committed by an employer against an employee, other than assault with purpose to injure, to be actionable at law.

In Johns-Manville Products, the employer fraudulently concealed from the employee-viction two iniportant facts. First, the employer failed to inform the employee of the dangers of exposure to carcinogenic asbestos dust in the Johns-Manville factory. In fact, the employer knowingly misrepresented the workplace as safe. The second concealment arose after a medical examination sponsored by the employer indicated that the plaintiff was suffermg from a degenerative lung disease caused by the inhalation of asbestos fibers. The einployer withheld this specific inedical information from the employee and the doctors retained by the employer to treat the plaintiff.

The court determined that injuries arising from the first concealment were compensable only through the workers' compensation system. ${ }^{3}$ The second concealment, however, was actionable in tort because it led to the aggravation of the "initial" work-related injury caused in part by the first concealment. ${ }^{4}$ The circumstance of aggravat-

\footnotetext{
1. 27 Cal. 3d 465, 612 P.2d 948, 165 Cal. Rptr. 858 (1980) (Mosk, J.) (4-2-1 decision).

2. Id. at 469,612 P.2d at 950,165 Cal. Rptr. at 860 .

3. Id. at $474-75,612$ P.2d at $954,165 \mathrm{Cal}$. Rptr. at 864 .

4. Id. at 477,612 P.2d at 955,165 Cal. Rptr. at 865 .
} 
ing concealment was held to justify a narrow exception to the general statutory rule that workplace injuries are to be remedied solely through the workers' compensation systein.

However narrow this exception, it punctures the employers' statutory shield against common law actions as no other statutory or judicial exception ever has. Previously, the courts allowed only intentional employer assaults to be actionable at law. Johns-Manville Products' aggravation exception marks the first time that a court has held that an injury which arises im the normal course of employment and which involves no imtent on the part of the employer to injure the employee directly may nevertheless be the subject of a tort action for tort remedies. This Note considers the analytical and policy rationales for this exception. It concludes that in hight of these rationales, the court's disparate treatment of Johns-Manville's two concealments was logically inconsistent.

Part I of this Note sets forth the facts of the case and the court's analysis. Part II examines the statutory foundations of the Cahfornia workers' compensation system and considers when that scheme will immunize employers from common law actions. The analysis in Part III demonstrates that the supreme court's expansion of employer liability in tort despite the generally exclusive nature of the compensation remedy was justified by recent trends in case law and by policy considerations. The analysis suggests that it would have been more consistent with these policy considerations for the court to have extended the tort option uniformly to any employee whose injuries are the result of imtentional employer misconduct, active or passive, that was substantially certaim to result in mjury to the employee and which was so egregious that deterring it through the imposition of punitive damages is justified.

\section{The CASE}

Plaimtiff, Reba Rudkin, worked in defendant Johns-Manville's asbestos factory for twenty-nine years. During that time, the concentration of asbestos dust in the factory exceeded the levels perinitted by federal and state regulations. In response to the plaintiff's inquiries as to the safety of the workplace, the employer assured liim that it was safe. The employer, however, knew this was not true.

During Rudkin's term of employment, he contracted pneumoconiosis, an asbestos-related lung disease. Evidence of this disease was de-

The Court noted that if the plaintiff was successful in establishing at the retrial that his injury was aggravated by the defendant's wrongful acts, the burden of apportioning the damages between the initial contracting of the disease and the subsequent aggravation would be placed on the defendant-employer. Id. at $477 \mathrm{n} .1 \mathrm{l}, 612$ P.2d at $956 \mathrm{n.11}, 165 \mathrm{Cal}$. Rptr. at $865 \mathrm{n} .1 \mathrm{I}$.

5. See Magliulo v. Superior Court, 47 Cal. App. 3d 760, 121 Cal. Rptr. 621 (Ist Dist. 1975). 
tected during medical examinations sponsored by the employer at the workplace. The employer, however, allegedly purposefully withheld from the plaintiff, the treating doctors, and the state the results of the exannination regarding the plaintiff's degenerative condition and the probable cause of that condition.

Thus, there were allegedly three acts by the employer that contributed to the plaintiff's asbestos-related disease. The first was the failure of the employer to provide his employees with a safe working environinent by allowing asbestos concentrations in the workplace to exceed regulatory limits and by failing to provide the workers with adequate protective devices. $^{6}$ The second act by the employer was the intentional misrepresentation of the workplace as safe. This induced the plaintiff to remain at the workplace and subject himself to continued exposure to the carcinogenic asbestos dust. The third act of employer misconduct involved the concealment of inedical data that indicated that the plaintiff was suffering from some forn of asbestosis. This concealment likewise contributed to the plaintiff remaining on the job and also kept him from seeking additional medical treatment. Plaintiff's condition was thus aggravated to the extent that it was allowed to degenerate beyond what it would have been had he been promptly informed of the medical findings.

The plaintiff brought the action in superior court and prayed for both general and punitive damages. This action was brought after the plaintiff had filed a claim with the Worker's Compensation Appeals Board. $^{7}$ This latter foruin is limited by statute and the California Constitution to making compensatory awards. ${ }^{8}$ It thus does not provide for the payment of general or punitive damages. Defendant JohnsManville moved that the tort action be dismissed on the basis of the Califorma workers' compensation statutes, which establish workers' compensation as the exclusive remedy for workplace injuries. The trial

6. 27 Cal. 3d at 469,612 P.2d at 950,165 Cal. Rptr. at 860 . Both federal and state standards were allegedly violated by the employer. For some of the current California requirements, see CAl. LAB. Code $\S 6408$ (West Supp. 1981).

7. The Worker's Compensation Appeals Board (WCAB) is an adjudicative board that decides the many unsettled compensation claims. 1ts predecessor was the Industrial Accident Commission, which was reorganized in 1965. The WCAB is not designed to handle intricate state-ofmind issues. In fact, only five of the seven board commissioners need be attorneys. It also has a heavy caseload. See S. Herlick, The California Workers' Compensation Handbook 1-3, 6 (1976).

Workers' compensation in California is quite generous compared to other states. It pays medical expenses and lost wages without any dollar limitation. Id. at 56. Still, this payment almost always falls short of general tort damages, since it does not include reimbursement for pain and suffering and punitive damages. The $\S 4553$ award for "serious and willful misconduct" is a type of penalty, but not an exemplary damage award, see notes 78-83 and accompanying text infra, which is used to ensure that the employer provides a safe place of employment. See Magliulo v. Superior Court, 47 Cal. App. 3d 760, 779, 121 Cal. Rptr. 621, 635 (1st Dist. 1975).

8. See notes $78-80$ and accompanying text infra. 
court refused to enter judgment for the defendant on the pleadings. Johns-Manville subsequently petitioned for a writ of mandate reversing the lower court's order. By the time the supreme court decided the petition, plaintiff Rudkin had died..$^{9}$

The court held that 'while the workers' compensation law bars the employee's action at law for his initial injury, a cause of action may exist for aggravation of the disease because of the employer's fraudulent concealment of the condition and its cause." 10 The court thus narrowly held that the concealment of inedical information regarding a work-related illness was actionable at law. However, the court treated the initial intentional misrepresentation of the asbestos hazard-which presumably contributed to the onset of the illness-as inerely a deliberate failure to ensure that the workplace was safe, ${ }^{11}$ and accordingly subject only to the coinpensation scheine.

The court looked to the perceived trend in Cahifornia law as well as public pohicy to justify its loolding. Reasoning from several recent California cases dealing with the exclusivity of workers' compensation, the majority held that actions at law can be maintained for injuries suffered in the course of einployment "if the employer acts deliberately for the purpose of injuring the employee or if the harm resulting from the intentional misconduct consists of aggravation of an initial workrelated injury." "12 On policy grounds, the court reasoned that the deterrence value of punitive damages in tort serves the societal interest in discouraging future egregious employer misconduct. ${ }^{13}$

Justice Clark, joined by Justice Richardson, dissented, arguing that no employer conduct short of deliberate assault should be actionable at law. The dissent argued that allowing any exceptions to the rule of exclusivity beyond those authorized by statute would unfairly shift the costs of the system against einployers, especially those who sponsor medical examination programs, ${ }^{14}$ and would ultimately cause such programs to be abandoned. The dissent also stressed that the inajority's judicially-created exception was wholly without statutory foundation, and attempted to distinguish the "trend setting" cases by finding statu-

9. 27 Cal. 3d at 470,612 P.2d at 95 I, I65 Cal. Rptr. at 86 I. The court held that the plaintiffemployee's death did not moot the cause of action, "since an action for personal injuries survives the death of the plaintiff." See CAL. PROB. CODE $\S 573$ (West 1970). The court also noted that the present action was consolidated with several other complaints with identical allegations filed by former employees at the same Johns-Manville plant. $27 \mathrm{Cal}$. 3d at $470 \mathrm{n} .3,612 \mathrm{P} .2 \mathrm{~d}$ at $951 \mathrm{n} .3$, 165 Cal. Rptr. at 861 n.3.

10. 27 Cal. $3 \mathrm{~d}$ at 469,612 P.2d at 950,165 Cal. Rptr. at 860 .

11. Id. at 474,612 P.2d at 953,165 Cal. Rptr. at 863.

12. Id. at 476,612 P.2d at 955,165 Cal. Rptr. at 865 . The cases relied on are discussed at notes $46-47,52-59,67-68,70-73$ and accompanying text infra.

13. 27 Cal. 3d at 478,612 P.2d at 956, 165 Cal. Rptr. at 866.

14. Id. at $481,488,612$ P.2d at 957, 962, 165 Cal. Rptr. at 867, 871 (Clark, J., dissenting). 
tory bases for their unique results. ${ }^{15}$

\section{II}

\section{CALIFORNIA WORKERS' COMPENSATION}

\section{A. The Statutes}

The California Constitution authorizes the establishment of a state workers' compensation insurance plan im which employees are effectively required to relinquish virtually all opportunities to sue their employers in tort in return for a complete and adequate system of worker compensation. ${ }^{16}$ It emphasizes that compensation should be granted "irrespective of the fault of any party." 17 This enabling language has been construed by the supreme court to mean that the legislature is empowered to grant benefits without having to factor in common law concepts of negligence. ${ }^{18}$

The state constitution, however, does not mandate a single comprehensive structure that must pre-empt common law actions for all conceivable workplace injuries. The legislature is therefore free to eliminate compensation awards based on the willful or intentional wrongdoing of an employer, opening the door for common law actions. On the other hand, the legislature is also free to increase the compensation to an employee under such circumstances, which would foreclose otlier civil actions. ${ }^{19}$

Section 3600 of the California Labor Code outlimes the basic conditions for compensation. ${ }^{20}$ of the conditions, the most important is that the mjury sustamed by the employee arise "out of and im the

15. Id. at 487,612 P.2d at 961,165 Cal. Rptr. at 871 (Clark, J., dissenting).

16. CAL. Const. art. XIV, $\S 4$ (formerly art. XX, $\S 21$, amended 1976). It currently reads in part:

The Legislature is hereby expressly vested with plenary power, unlimited by any provision of this Constitution, to create and enforce a complete system of workers' compensation, by appropriate legislation, and in that behalf to create and enforce a liability on the part of any or all persons to compensate any or all of their workers for injury or disability, and their dependents for death incurred or sustained by said workers in the course of their employment, irrespective of the fault of any party. . . .

The Legislature is vested with plenary powers, to provide for the settleinent of any disputes arising under such legislation by arbitration, or by an industrial accident commission, by the courts, or by either, any, or all of these agencies . . . provided that all decisions of any such tribunal shall be subject to review by the appellate courts of this State.

17. Id.

18. Mathews v. Workmen's Comp. Appeals Bd., 6 Cal. 3d 719, 728, 493 P.2d 1165, 1170, 100 Cal. Rptr. 301,306 (1972).

19. Id.

20. CAL. LAB. CODE $\S 3600$ (West Supp. 1981). It reads in part:

Liability for the compensation provided by this division, in lieu of any other liability whatsoever to any person except as provided in Section 3706, shall, without regard to negligence, exist against an employer for any injury sustained by his employees arising out of and in the course of the employment and for the death of any employee if the 
course of employment."21 If the mjury arises withm the scope of employment, the statute provides for compensation "in lieu of other liability . . . without regard to negligence."22

Section 3601 clearly specifies that "tlie right to recover such compensation . . . is the exclusive remedy for injury or death of an employee agamst the employer ...."23 There are two statutory exceptions to workers' compensation exclusivity. Tlie injured em-

imjury proximately causes death, in those cases where the following conditions of compensation concur:

(a) Where, at the time of the injury, both the employer and the employee are subject to the compensation provisions of this division.

(b) Where, at the time of the injury, the employee is performing service growing out of and incidental to his employment and is acting within the course of his employment

(c) Where the imjury is proximately caused by the employment, either with or without negligence.

(d) Where the injury is not caused by the intoxication of the injured employee.

(e) Where the injury is not intentionally self-inflicted.

(f) Where the employee has not willfully and deliberately caused his own death.

(g) Where the injury does not arise out of an altercation in which the injured employee is the initial physical aggressor.

Unless noted otherwise, all references in text to statutory sections are to the California Labor Code.

21. Id.

22. Id. On its face, the statute neither specifically includes nor excludes intentional injuries. In the past, courts have used this language to deny workers' compensation coverage for intentional injuries. See Conway v. Globin, 105 Cal. App. 2d 495, 498, 233 P.2d 612, 614 (3d Dist. 1951). California moved beyond this treatment in Carter v. Superior Court, 142 Cal. App. 2d 350, 354, 298 P.2d 598, 601 (2d Dist. 1956).

Ironically, California employers, who once inaintained that the absence of statutory language as to intentional injuries meant that such injuries were not compensable, recently have contended that intentional injuries do inplicitly meet the conditions of coverage, hence triggering workers' compensation as the exclusive reinedy. Compare Conway v. Globin, $105 \mathrm{Cal}$. App. 2d 495, 233 P.2d 612, with Magliulo v. Superior Court, 47 Cal. App. 3d 760, 763-64, 121 Cal. Rptr. 621, 624 (1st Dist. 1975) and Azevedo v. Abel, 264 Cal. App. 2d 451, 454, 70 Cal. Rptr. 710, 711-12 (3d Dist. 1968).

23. CAL. LAB. Code $\S 3601$ (West Supp. 1981). It reads in part:

(a) Where the conditions of compensation exist, the right to recover such compensation, pursuant to the provisions of this division is, except as provided in Section 3706, the exclusive remedy for injury or death of an employee against the employer or against any other employee of the employer acting within the scope of his employment, except that an einployee, or his dependents in the event of his death, shall, in addition to the right to compensation against the employer, have a right to bring an action at law for damages against such other employee, as if this division did not apply, in either of the following cases:

(1) When the injury or death is proximately caused by the willful and unprovoked physical act or aggression of such other employee.

(2) When the injury or death is proximately caused by the intoxication of such other employee.

(b) An act which will not sustain an indepeudent action for damages against such other employee under paragraph (1) or (2) of subdivision (a) of this section inay nevertheless be the basis of a finding of serious and willful misconduct under Section 4553 or 4553.1 , if (1) such other employee is established to be one through whoin the employer may be charged under Section 4553; (2) such act of such other employee shall be established to have been the proximate cause of the injury or death; and (3) such act is established to have been of a nature, kind, and degree sufficient to support a finding of serious and willful unisconduct under Section 4553 or 4553.1 . 
ployee inay collect damages in tort froin another employee if the injury was caused either by the other einployee's willful and unprovoked physical act of aggression ${ }^{24}$ or by his intoxication..$^{25}$

While section 3601 says nothing about similar acts of aggression by the employer, section 4553 specifically addresses the issue of especially hazardous employer action. Section 4553 provides that the compensation award will be increased by fifty percent where the employee is injured by the "serious and willful misconduct" of the corporate einployer. ${ }^{26}$ This additional award has a $\$ 10,000$ linit; however, the employer cannot purchase insurance to cover this penalty.

\section{B. Scope of Section 4553}

At issue in Johns-Manville Products was the reach of section 4553. Case law and legislative history clearly indicate that "serious and willful inisconduct" includes employer recklessness. Appellate courts have sphit, however, on the issue of whether section 4553 covers intentional employer misconduct. ${ }^{27}$

In interpreting the scope of "serious and willful misconduct," the California Supreme Court has held that it covers employer recklessness. In E. Clemens Horst Co. v. Industrial Accident Commission, ${ }^{28}$ the court upheld an employee's award of one-half additional compensation for injuries caused by an employer's knowing failure to inaintain safe working conditions. ${ }^{29}$ The court held that serious and willful misconduct required only that the einployer "evince a reckless disregard for the safety of others, and a willingness to inflict the injury complained of." ${ }^{30}$ In Rogers Materials Co. v. Industrial Accident Commission, ${ }^{31}$ the

24. Id. $\S 3601(\mathrm{a})(1)$.

25. Id. $\S 3601(\mathrm{a})(2)$.

26. Id. $\S 4553$ (West Supp. 1981). It reads:

The amount of compensation otherwise recoverable shall be increased one-half whcre the employee is injured by reason of the serious and willful misconduct of any of the following:

(a) The employer, or his managing representative.

(b) If the employer is a partnership, on the part of one of the partners or a managing representative or general superintendent thereof.

(c) If the employer is a corporation, on the part of an executive, managing officer, or general superintendent thereof.

But such increase of award shall in no event exceed ten thousand dollars $(\$ 10,000)$; together with costs and expenses incident to procurement of such award, not to exceed two hundred fifty dollars (\$250).

27. See notes 34-38 and accompanying text infra.

28. 184 Cal. 180,193 P. 105 (1920).

29. Id. at I88-89, 193 P. at 108 .

30. Id. at $189,193 \mathrm{P}$. at 109.

Other California appellate courts have required only that the employer "knew or should have known of the dangers." The supreme court, in Parkhurst v. Industrial Accident Comm'n, 20 Cal. 2d 826, 129 P.2d 113 (1942), held that serious and willful misconduct amounted to conduct that the employer knew or should have known was likely to cause serious injury, or conduct that 
court allowed a section 4553 recovery where the employer "permitted" the claimant to be im a position of danger known both to the employer and the employee..$^{32}$

Legislative history also supports the notion that section 4553 was meant to apply to grossly neghigent and reckless acts. The one-half additional compensation remedy was added at the same time the legislature chose to delete a provision allowing for an elective remedy in tort for the employee "in the event of gross neghigence or willful misconduct by the employer." ${ }^{33}$ The Johns-Manville Products court beheved that the deletion of this provision coupled with the section 4553 penalty award indicated that the legislature intended to preclude tort actions for all intentional workplace imjuries inflicted by the einployer, despite the fact that neither the deleted provision nor section 4553 exphicitly referred to intentionally caused injuries. They referred only to willful imisconduct, a label whose definition remains uncertam.

"Willful misconduct" certainly mcludes recklessness. Whether it includes intentional misconduct, however, is in doubt. Until recently, intentional misconduct was presumed to have been covered by the statute. $^{34}$ But in a recent appellate court ruling, Magliulo v. Superior Court $^{35}$ - a case rehed on extensively by Johns-Manville Products-the court held that willful misconduct involves acts in the zone between negligent and intentional misconduct. ${ }^{36}$

The Johns-Manville Products court held that section 4553 covers intentional misconduct. ${ }^{37}$ The court, however, belied its own categorization by ultimately holding that certam types of intentional misconduct are im fact beyond the exclusive scope of the compensation scheme and are actionable at law. ${ }^{38}$

evinced a reckless disregard for the safety of others. Id. at 829,129 P.2d at 115 . See also W. Prosser, THE LAW OF TORTS \& 34, at 184 (4th ed. 1971).

31. 63 Cal. 2d 717, 408 P.2d 737, 48 Cal. Rptr. 129 (1965).

32. Id. at 719,408 P.2d at 739,48 Cal. Rptr. at 131 .

33. The first workers' compensation act in California was the Roseberry Act, in which there was an elective remedy for the employee in the event of gross negligence or willful misconduct by the employer. 1911 Cal. Stats. ch. 399, \& 3(3) at 796-97. When this provision was deleted, the onehalf additional compensation remedy for serious and willful unisconduct was added. $1917 \mathrm{Cal}$. Stats. ch. 586, § 6(b) at 831,834 .

34. See Azevedo v. Abel, 264 Cal. App. 2d 451, 70 Cal. Rptr. 710 (3d Dist. 1968).

35. 47 Cal. App. 3d 760, 121 Cal. Rptr. 621 (1st Dist. 1975).

36. Id. at 778-79, 121 Cal. Rptr. at 634-35.

37. 27 Cal. 3d at 473,612 P.2d at 953,165 Cal. Rptr. at 863.

38. Although compensation schemes, as well as physical and population characteristics among the states, differ, the benign experiences of other states may liave some probative value for California regarding exclusivity exceptions for intentional injuries. Oregon and Utah provide two western examples. In 1975, the Utah Supreme Court lield that the state workers' compensation act prohibiting actions at law does not destroy the mamtenance of actions for damages due to intentional infliction of injury. While the Utah case did not involve recovery agamst an employer, but rather a fellow einployee, the court indicated that a cause of action could also lave been stated 


\section{III}

\section{ANALYSIS}

The Johns-Manville Products court chose to limit tort actions to "injuries suffered in the employment if the employer acts deliberately for the purpose of injuring the einployee or if the harm resulting from the intentional misconduct consists of aggravation of an intitial workrelated injury." 39

Because Johns-Mansville Products clearly did not involve purposeful employer acts to deliberately injure the employee, ${ }^{40}$ the court focused on the second branch of actionable injuries-those which amount to an aggravation, through intentional misconduct, of an original workplace injury. In applying this standard, the court held that the concealment of medical information relating to the employee's workrelated illness was actionable in tort. ${ }^{41}$ However, the complementary cause of action, the concealment and misrepresentation of known environmental hazards, was held not to be maintainable. ${ }^{42}$ The employee's exclusive remedy for such misconduct was workers' compensation. This Note argues that the majority's rigid distinction between two aspects of employer concealment is logically inconsistent, and produces results that are at odds with the legal principles and social policies that justify an action in tort for egregious employer misconduct.

\section{A. Intentional Employer Misconduct Goes Beyond Exclusive Workers' Compensation Remedies}

\section{Case Law}

In cases involving intentional employer misconduct, California courts have pursued two divergent lines of authority. One line has held that intentional misconduct is covered exclusively by the workers' compensation statute so long as the injury arose "out of and in the course of employinent." ${ }^{\text {43 }}$ Such analysis has held that willful misrepresentation of hazardous substances used on the job is conduct exclusively covered

against an employer. Bryan v. Utah Int'l, 533 P.2d 892 (Utah 1975) (construing a statute similar to CAL. LAB. CODE $§ 4553$ to allow common law suit for intentional injuries). See also Collier v. Wagner Castings Co., 70 Ill. App. 3d 233, 388 N.E.2d 265 (1979) (implying that Illinois Workmen's Compensation Act § 5(a), ILL. Rev. STAT. ch. 48, § 138.5(a) (1973), allows an exclusivity exception for intentional infliction of injury on an employee by an employer), aff'd, 81 Ill. 2d 229, 408 N.E.2d 198 (1980); OR. REv. STAT. § 656.156 (1979-80) (long provided an exclusivity exception for intentional injuries, apparently without dire consequences in Oregon).

39. $27 \mathrm{Cal} .3 \mathrm{~d}$ at $476,6 \mathrm{I} 2 \mathrm{P} .2 \mathrm{~d}$ at $955,165 \mathrm{Cal}$. Rptr. at 865.

40. See text accompanying notes 73-74 infra.

41. 27 Cal. 3 d at 477,612 P.2d at 955,165 Cal. Rptr. at 865 .

42. Id.

43. See, e.g., Azevedo v. Abel, 264 Cal. App. 2d 451, 70 Cal. Rptr. 710 (3d Dist. 1968); Buttner v. American Bell Tel. Co., 41 Cal. App. 2d 581, 107 P.2d 439 (2d Dist. 1940). 
by the statute. ${ }^{44}$ This rationale was extended to its fullest in Azevedo $v$. Abel, ${ }^{45}$ where an intentional assault at the workplace was held to be exclusively remedied by workers' compensation because the assault arose during the course of employment.

Other California courts have questioned this total exclusivity line of cases and have established limitations as to what injuries the compensation statute can reach. These limitations have generally been grounded in strict interpretations of the terms "course of employnent" and "employer." The forner limitation recognizes that an injury occurring at the workplace is not necessarily one arising out of conditions incident to the employment. For example, intentional employer assaul $t^{46}$ and fraudulent misrepresentation ${ }^{47}$ have been characterized as

44. Workers' compensation was held to be the exclusive remedy in Buttner v. American Bell Tel. Co., 41 Cal. App. 2d 581, 107 P.2d 439, where an employer willfully misrepresented to the employee the hazardous nature of a chemical used on the job. The worker was seriously injured when he inadvertently came into contact with that substance. Despite the egregious deceit, the court held that general damages in tort were precluded because the injury clearly arose "out of and in the course of employinent." Id. at 583, 107 P.2d at 440.

In considering Buttner, it is crucial to note that the case was decided in an era in which an injury could be actionable in tort only if it was not conpensable under the $\S 3600$ conditions. See Conway v. Globin, 105 Cal. App. 2d 495, 498, 233 P.2d 612, 614 (3d Dist. 1951). The court would naturally be unwilling to deprive the worker of the certain compensation reinedy, even for the possibility of a larger tort recovery.

Moreover, the court explicitly refused to address whether the result would have been different had the worker prayed for punitive damages. 41 Cal. App. $2 \mathrm{~d}$ at 585, 107 P.2d at 441 .

A more recent appellate case with facts similar to Johns-Manville Products, Wright v. FMC Corp., 81 Cal. App. 3d 777, 146 Cal. Rptr. 740 (1st Dist. 1978), relied upon Buttner while curtly upholding the dismissal of an employee's complaint seeking tort recovery for injuries allegedly suffered while he inixed dangerous chemicals on the job. Once again, the allegation of concealinent and misrepresentation of environmental hazards that ultimately caused the injury was deemed insufficient alone to overcome the exclusiveness of workers' compensation provisions. Id. at 779,146 Cal. Rptr. at 740.

45. 264 Cal. App. 2d 451, 70 Cal. Rptr. 710 (3d Dist. 1968). The Azevedo court explained that as long as the conditions of $\$ 3600$ were inet, and the WCAB had accepted jurisdiction and had already made an award, the plaintiff-employee had no opportunity either to supplement the compensation award or to replace it altogether with tort danuages.

46. See, e.g., Conway v. Globin, 105 Cal. App. 2d 495, 233 P.2d 612 (3d Dist. 1951). Conway held that although assaults by fellow employees are compensable when fairly traceable to an incident of employment, intentional assaults by the employer are not risks or conditions incident to the employment at all. The court reasoned that to hold the assault withm the conditions of coverage would not only "sanction indirectly conduct of the employer which is both tortious and criminal, but would also be to permit the einployer to use the Workmen's Compensation Act to shield him from his larger civil liability . . ." Id. at 498, 233 P.2d at 614 . Ironically, the court effectively required that the employee succeed in his tort claim; otherwise, he would be left without any remedy at all. See note 22 supra.

47. In Ramey v. General Petroleum Corp., 173 Cal. App. 2d 386, 343 P.2d 787 (2d Dist. 1959), the court considered an intentional fraud to have arisen outside the scope of employinent. In Ramey, plaintiff had already recovered workers' compensation for his initial workplace injury in the oilfield, but his einployer fraudulently concealed from him the fact that an unknown third party had been involved along with the employer as a co-partner in causing the original compensable injury. The third party could have been sued for tort dainages beyond the workers' coinpen- 
being beyond the risks normally associated with employment.

The exclusivity of the statutory scheme has also been pierced when the defendant is treated as a "person other than the employer." 48 At its simplest, this "dual capacity" doctrime has been invoked where the einployer is concurrently acting $\mathrm{m}$ another capacity. The seminal case of Duprey v. Shane ${ }^{49}$ serves as an example. There, a doctor was held liable at common law after negligently treating an mjured patient, who also happened to be his employee. The court determmed that the $\mathrm{m}$ jury resulted from the defendant actimg in a medical capacity, distinguishable froin his role as the victim's employer. ${ }^{50}$

The theories developed by Cahforma courts in these cases to circumvent the broad legislative exclusivity language generally are based on reasonable interpretations of the facts and statutes at issue $\mathrm{m}$ those cases. However, reliance on any of those approaclies in the JohnsManville Products situation would twist them imto inappropriate legal fictions. Plaimtiff's imjuries arose "out of and in the course of employment," smce his injuries were directly attributable to asbestos in the workplace; the employer's acts of concealment, unlike an act of assault,

sation provisions if plaintiff had known that fact before the tort statute of limitations had expired. The court found that the injury caused by fraud was not "proximately caused by the employmcnt" and did not arise "out of and in the course of employment." Id. at 403, 343 P.2d at 797. The court concluded that fraud was not a risk of employment, id. at 402-03, 343 P.2d at 796-97, and therefore was not subject to the limited remedies of workers' compensation.

48. See, e.g., Unruh v. Truck Ins. Exch., 7 Cal. 3d 616, 498 P.2d 1063, 102 Cal. Rptr. 815 (1972); Duprey v. Shane, 39 Cal. 2d 781, 249 P.2d 8 (1952).

49. 39 Cal. 2d 781, 249 P.2d 8 (1952).

50. Id. at 793,249 P.2d at 15 .

The "dual capacity" rationale has been extended to instances where the employer is the manufacturer of a product that injures the employee. The employer's duty to his employecs is coextensive with that to the public in product liability cases. The imjured employce may sustain a strict liability action in tort when mjured by a defective product in the course of employment. See Douglas v. E. \& J. Gallo Winery, 69 Cal. App. 3d 103, 137 Cal. Rptr. 797 (5th Dist. 1977). Such a rationale was unavailable to the plaintiff in Johns-Manville Products. His injuries were not proximately caused by the faulty design or manufacture of a product, but rather by the ambient workplace conditions.

The California Supreme Court resurrected the dual capacity doctrine to articulate an exception to the exclusivity rule for intentional torts committed by the employer's compensation insurer. In Unruh v. Truck Ins. Exch., 7 Cal. 3d 616, 498 P.2d 1063, 102 Cal. Rptr. 815 (1972), the plaintiff suffered physical and mental injuries from the intentional acts of imsurance carriers who sought to discredit her claim to compensation for an injury sustained years earlier. Unruh recognized that under the coinpensation statutes the insurer was an alter ego of the employer. The court held that an insurer who committed negligent acts maintained this alter ego status; however, if he committed an intentional tort, the insurer "stepped out of its proper role" as an einployer. Id. at 625,498 P.2d at 1069, 102 Cal. Rptr. at 821. See generally Demler, Remedy for Intentional Torts of a Workmen's Compensation Carrier, 1 PEPPERDINE L. Rev. 54 (1973) (strongly disapproving of Unruh's dual capacity approach, and pointing to the paradox of the carrier receiving greater immunity than the employer from negligence tort actions); Hanna, Exclusivity of Workmen's Compensation Remedy in Relation to Further Injury Resulting From Carrier's Nonmedical Investigation of Employee's Industrial Disability, 5 Sw. U.L. REv. 118 (1973) (disapproving of inroads on exclusivity). 
for example, were only passive, contributing causes of the injury. Moreover, for the court to hold that defendant Johns-Manville became a "person other than the employer" by colnmitting intentional acts of concealment would amount to a characterization that is "unreahstic and purely legalistic,"s1 since there was never a severance of the enployment relationship, nor did the einployer purport to act in another capacity toward the plaintiff-einployee.

\section{The Magliulo Rationale}

In noting that in certain instances, intentional injuries committed by an employer against an employee in the workplace are not covered by the statutory scheme for exclusive coinpensation reinedies, the Johns-Manville Products inajority took note of the analysis used in Magliulo v. Superior Court, ${ }^{52}$ an intentional einployer assault case ${ }^{53}$ from the court of appeals. The Magliulo rationale was inarkedly different from the previous limes of cases. Instead of looking inerely to see if the conditions of the statute were inet, Magliulo focused on the expectations created by the statute.

The Magliulo court first concluded that neither legislative intent ${ }^{54}$ nor the pohicies that support the statutory scheme ${ }^{55}$ preclude actions at law for intentional assaults at the workplace. The Magliulo court thus rejected the suggestion that employees working within the scope of their employment necessarily surrendered all their rights to sue in tort for intentional injuries. Magliulo supported this proposition by analogizing employer assault to the section 3601 einployee assault exception to workers' coinpensation exclusivity. ${ }^{56}$ The court reasoned that an einployee no more expected to be assaulted by an einployer on the job

51. See Unruh v. Truck Ins. Exch., 7 Cal. 3d at 635, 498 P.2d at 1077, 102 Cal. Rptr. at 829.

52. 47 Cal. App. 3d 760, 121 Cal. Rptr. 621 (1st Dist. 1975). This reasoning was also relied upon in Meyer v. Graphic Arts Int'l Union, 88 Cal. App. 3d 176, 151 Cal. Rptr. 597 (2d Dist. 1979) (overturning defendant's demurrer to rape, false imprisonment, and other physical assault counts against employer).

53. On its facts, Magliulo presents a companion to Azevedo v. Abel, 264 Cal. App. 2d 451, 70 Cal. Rptr. 710 (3d Dist. 1968), which also involved an intentional enployer assault at the workplace. The holdings of these decisions are dianetrically opposed. The California Supreme Court has not to date decided a case in the context of intentional assault. However, the langauage in Johns-Manville Products indicates that the court probably is prepared to acknowledge the actionability of intentional employer assaults in tort. $27 \mathrm{Cal}$. 3d at 476, $612 \mathrm{P} .2 \mathrm{~d}$ at $955,165 \mathrm{Cal}$. Rptr. at 865.

54. 47 Cal. App. 3d at 777-78, 121 Cal. Rptr. at 634 . See also notes 56,75 , and accompanying text infra.

55. 47 Cal. App. 3d at 778, 121 Cal. Rptr. at 634.

56. It is significant that Magliulo never claimed to be inerely interpreting the explicit language of the statute. Rather, it inore broadly filled in logical gaps left by the legislature. In fact, Magliulo stated that "in the absence of a controlling statute the courts are free to determine whether the einployer loses his immunity from civil suit in the event lie personally intentionally inflicts an injury on the person of his employee." Id. at 769, 121 Cal. Rptr. at 628. Since Magliulo 
than by a fellow employee, ${ }^{57}$ and did not expect the remedies for such assaults to be different. ${ }^{58}$

The Magliulo court further noted that while the workers' compensation system is legitimated by an exchange of disability insurance for the right to sue for damages, this tradeoff is limited to injuries that most employees would consider to be work-related. The court stated:

It may be rational to imply that an employee is willing to surrender common law rights and disabilities, which he never knew he had or suffered, for what most employees are actually cognizant of-compensation and medical care for work-related injuries. It is not so clear . . . that his employer is going to assault him, or that if he does, the employee will have to be satisfied with an award of one-half the compensation . . . with a limit . . [of] $\$ 10,000 \ldots .59$

Of critical importance is the observation that the court looks to the expectations of "most employees," a necessarily objective standard, rather than the subjective expectation of the individual plaimtiff.

The expectations analysis can be characterized in one of two ways. Either the court inquires into whether the employee would reasonably consider the injurious act to be work-related, or it reflects upon the employee's reasonable expectations as to workers' compensation coverage. In short, the court attempts to ascertain where the reasonable employee perceives the limits of his tradeoff of rights of action in return for swift and certain compensation to be.

The Johns-Manville Products court applied Magliulo's objective expectation analysis to its fact situation. The majority asserted that it is inconceivable that the employee "contemplated defendant would, as he alleges, intentionally conceal the knowledge that he contracted a serious disease from the work environment, thereby aggravating the disease, and by accepting employment he would surrender his right to damages at law for such conduct." 60 Yet when the Magliulo court considered employee objective expectations, it had a statutory foothold-

reads $\S 3601$ in conjunction with the $\$ 3600$ phrase, "without regard to negligence," the latitude to pursue tort remedies should exist in all cases of intentional employer misconduct.

The dissent in Johns-Manville Products clains that Magliulo is merely a narrow construction of $\S 3601$. In this way the dissent attempts to distinguish the purposeful assault exception in Magliulo as one based on the statute froin the Johns-Manville Products exception for other intentional conduct. 27 Cal. 3d at 486, 612 P.2d at 960, 165 Cal. Rptr. at 870 (Clark, J., dissenting).

57. 47 Cal. App. 3d at 772-73, 121 Cal. Rptr. at 630-31.

58. Id. at 778, 121 Cal. Rptr. at 635.

59. Id.

60. 27 Cal. 3d at 477,612 P.2d at $955-56,165$ Cal. Rptr. at 865 .

Within the objective expectation perspective, it may seen arbitrary to draw the line of legitimate expectations at intentional misconduct, but the legislature essentially preempted the judgment on reckless conduct by enacting $\S 4553$. For a discussion of $\S 4553$, see notes $26-37$ and accompanying text supra. 
the exemption of co-employee assault at the workplace. ${ }^{61}$ The JohnsManville Products court, however, did not have such a statutory foundation from which to derive reasonable employee expectations. Accordingly, it is worth considering an independent conceptual justification for the objective expectation rationale.

The objective expectation perspective has its foundation in viewing the workers' compensation scheme as a type of social contract. Although California courts have frequently stated that the individual's right to compensation derives legislatively from one's status as an employee, and not from implied contract or tort principles, ${ }^{62}$ the system nevertheless resembles a collective agreement between the employee, the employer, and the state. Employees are assured of compensation coverage at the expense of relinquishing possible actions at law. ${ }^{63} \mathrm{Em}$ ployers must pay insurance premiums, but may rely on them to provide exclusive coverage for injuries and immunity from huge tort claims, so long as the employers do not breach the statutory conditions, ${ }^{64}$ or act outside the course of einployment ${ }^{65}$

In this contract, the parties have agreed to participate in the scheme insofar as it allocates rights and remedies for injuries resulting from neghigent, as well as serious and willful acts. Magliulo and JohnsManville Products indicate, however, that the serious and willful standard does not cover all intentional employer misdeeds. In other words, the parties have not "contractcd" as to the allocation of remedies for injuries arising from particularly egregious intentional misconduct. The workers' compensation scheme may thus be viewed as a partially integrated contract that does not address, and therefore does not negate, the right to bring an action at law for certain mjurious acts.

In determining whether an action is covered by the contract, the court considers what the employer and the einployee reasonably expected of the prograin according to an objective theory of contracts. ${ }^{66}$ Although the broad language of Magliulo suggests that all intentional

61. See note 56 and accompanying text supra.

62. See generally Argonaut Mining Co. v. Industrial Accident Comm'n, 104 Cal. App. 2d 27, 230 P.2d 637 (1st Dist. 1951); Record v. Indemnity Ins. Co., 103 Cal. App. 2d 434, 229 P.2d 85I (1st Dist. 1951). However, the stated axiom that workers' compensation is not a contractual right is directed to the individual's right of recovery. It does not necessarily detract from the collective contract model.

63. Employees are assured of compensation coverage as long as the injuries meet the conditions of the statutes. See CAL. LAB. CODE $\$ 3600$ (West Supp. 1981).

64. CAL. LAB. CODE $\S 3706$ (West Supp. 1981) (dealing with nonpayment of insurance premiums). An employer can still refuse to participate in the workers' compensation scheme by not making the premium payments, but $\S 3706$ expressly provides that a civil action can be pursued by an injured employee in such instances. Moreover, the employer will still be liable for the compensation payinents. $I d . \S 3715$.

65. See notes $43-47$ and accompanying text supra.

66. See generally 4 S. WILliston, ConTRACTs $§ 605$ (3d ed. 1961). 
injuries brought about by the employer are beyond the reasonable expectations of the parties, ${ }^{67}$ the Johns-Manville Products dissent notes that the Magliulo holding could be limited on its facts to cases of physical assault by employers. ${ }^{68}$ However, if one accepts that the basis for Magliulo was an objective search for the parties' expectations, then that approach was properly applied in Johns-Manville Products. First, the contract theory of workers' compensation cannot logically be limited in application only to cases of actual assault; if anything, it should be applied to any action not expressly addressed by the statute. Second, in applying the analysis to Johns-Manville's actions, the majority reasonably held that intentional concealment of a inedical diagnosis by a corporate employer is no inore a conteinplated risk of employment than is assault by one's employer. ${ }^{69}$

\section{The Court's Approach: Aggravation of the Initial Injury}

The Johns-Manville Products court held that an employer's intentional act that aggravates an initial work-related injury is actionable in tort. The court incorrectly relied on Ramey v. General Petroleum Corp. ${ }^{70}$ and Unruh v. Truck Insurance Exchange ${ }^{71}$ as authority for the proposition that an aggravating injury may be remedied at law. Those cases represent instances where a court found that the statutory prerequisites for workers' compensation hability were not met. ${ }^{72}$ Moreover, neither case hinged on physical aggravation of an existing injury, but rather on an injury unrelated to the initial injury. Unruh involved a former employee's nervous breakdown that was only tangentially related to her initial employment injury. Ramey dealt with the loss of a financial opportunity and involved no physical aggravation at all. ${ }^{73}$

67. 47 Cal. App. 3d at 778, 121 Cal. Rptr. at 634-35; see note 56 supra.

68. 27 Cal. 3d at 486, 612 P.2d at 960, 165 Cal. Rptr. at 870 (Clark, J., dissenting); see note 56 supra.

69. 27 Cal. 3d at 477,612 P.2d at 955-56, 165 Cal. Rptr. at 865.

Although Magliulo relied in part on the otherwise asymmetric treatment of injuries resulting from an assaulting employer and an assaulting fellow employee, see note 56 and accompanying text supra, it did not address the intentional acts of a corporate entity. Johns-Manville Products did not consider the impersonal nature of the tortfeasor to be significant, however. A coherent social policy demands that corporations assume the responsibility to refrain from committing intentional tortious conduct through their directors or managers. Thus, the corporation should be subject to the panoply of tort remedies, including exemplary damages. See note 81 and accompanying text infra.

70. 173 Cal. App. 2d 386, 343 P.2d 787 (2d Dist. 1959).

71. 7 Cal. 3d 616, 498 P.2d 1063, 102 Cal. Rptr. 815 (1972).

72. Ramey held that the fraud did not occur in tlie course of employment. $173 \mathrm{Cal}$. App. 2d at 402-03, 343 P.2d at 797. Uhruh is somewhat unclear on whetlier the insurance carrier's intentional torts were compensable at all. However, Unruh determined that the aggressor was not an "employer." 7 Cal. 3d at 624-25, 498 P.2d at 1069, 102 Cal. Rptr. at 821. See notes 48-51 and accompanying text supra.

73. See note 47 supra. 
The aggravation standard set by the court may appear to be a narrow exception to the exclusive remedy of compensation. However, it marks the first time that any California appellate court has recognized that something other than purposefully injurious employer conduct directed agamst an employee may be actionable at law. Given the industrial setting of Johns-Manville Products, one must believe that the employer did not intend to cripple his blue collar work force. JohnsManville was therefore different from the employer who deliberately and actively assaults an employee with the intent to injure him or her. The court did not offer a rationale for allowing intentional, though not purposefully injurious, conduct to pierce the statutory shield. However, one principle can be extracted froin the parallel assault exception which, when apphed to the aggravation problem, reasonably explains and himits that exception: intentional employer acts that are substantially certain to result in physical injury to an employee will be actionable at law.

Intentional acts, as a general matter, are covered by the workers' compensation scheme, according to the Johns-Manville Products court's reading of section $4553 .^{74}$ Dehiberate, mtentional assault, however, is one recognized exception. One explanation for the court's characterization of imtentional aggravation as an additional excepted action is that the intentional aggravation in Johns-Manville Products, like assault, mvolved a high degree of certainty that an injury, albeit one related to an old mjury, would result. The plaintiff had already been mjured and was therefore particularly susceptible to comphications and degeneration owing to a lack of adequate treatment and continued exposure to asbestos dust. Arguably, since both assault and intentional aggravation involve conduct that is deliberate and substantially certaim to be physically injurious, they should both be accorded the same legal treatment. In short, both should be excepted from the general rule of workers' compensation exclusivity. ${ }^{75}$

Not all intentional misconduct, however, involves a substantial certaimty of physical injury. Fraudulent concealment, the alleged einployer misconduct in Johns-Manville Products, serves to illustrate this poimt. The concealment of medical data was virtually certain to result in contimued lung damage to the employee. The fraudulent conceal-

74. 27 Cal. $3 d$ at 473,612 P.2d at 953,165 Cal. Rptr. at 863 .

75. Legislative history arguably indicates that the statute was meant to exempt a broader range of intentional acts. Before it was amended in 1971, CAL. LAB. CODE $\$ 3601$ (a)(3) exempted injuries caused by the recklessness of a fellow employee. This statutory modification suggests that the legislature sought to exempt only intentional employee misconduct from the otherwise exclusive statutory scheme. If co-employee deceit would in fact be actionable in tort, then it follows from Magliulo that employer deceit whose effect is substantially certain to be injurious should receive the same treatment. 
ment of a potential cause of action in Ramey, on the other hand, only deprived the plaintiff of a financial opportunity. Moreover, one can imagine situations where an employer makes intentional inisrepresentations to its employees that are unlikely to affect their well-being at all. For example, if an einployer fraudulently conceals that the workplace will be unsafe in the event of an earthquake, the unlikelihood of an earthquake in the area might inean that the employer's misrepresentation is not substantially certain to result in employee injury. Any injuries that might occur in such a situation would be covered by the workers' coinpensation scheine that awards compensation even for the deliberate failure of an employer to ensure that the workplace is safe. ${ }^{76}$

The element of substantial certainty may distinguish the concealment in Johns-Manville Products from the misrepresentations made in the earlier hazardous workplace cases that limited the available remedies to statutory compensation. The leading case is Buttner v. American Bell Telephone. ${ }^{77}$ In Buttner, the employer told the plaintiff that a certain substance he worked with was harmless, when in fact the substance was carbon tetrachloride, sufficiently concentrated to injure the employee when he caine into contact with it. Yet, in Buttner, as in similar cases, the plaintiff's inadvertant contact with the carbon tetrachloride imght liave been an improbable accident. These cases do not discuss the probabilities of the einployees coining into contact with the harmful substances. They therefore leave open the possibility that the injuries arose froin accidental contacts with the substances, rather than from inevitable, constant exposure to the dangerous inaterials.

\section{The Policy Behind Punitive Damages}

The California Supreme Court has suggested that the workers' compensation system is solely compensatory and does not have a deterrence component built into it. ${ }^{78}$ The court has described the section 4553 award as "not a penalty in the sense of being designed primarily to punish the defendant rather than to more adequately coinpensate the plaintiff." 79 In fact, the court has observed that the workers' compensation system would be in violation of its constitutional mandate if it provided for punitive damages. ${ }^{80}$ However, the Johns-Manville Products

76. See 27 Cal. $3 d$ at 472 n.6, 612 P.2d at 952 n.6, 165 Cal. Rptr. at 862 n.6.

77. 41 Cal. App. 2d 581, 107 P.2d 439 (2d Dist. 1940).

78. E.g., State Dept. of Corrections v. Workmen's Comp. Appeals Bd., 5 Cal. 3d 885, 888-91, 489 P.2d 818, 820-22, 97 Cal. Rptr. 786, 788-90 (1971).

79. Id. at 890,489 P.2d at 821,97 Cal. Rptr. at 789 .

80. In E. Clemens Horst Co. v. Industrial Accident Comm'n, 184 Cal. 180, 193 P. 105 (1920), the California Supreme Court stated that if the one-half additional compensation award is "given as a penalty for such misconduct, and not as compensation to the employee for his injury, the provision is not within the power given to the legislature by said section [CAL. CONST. Art. XX, 
court noted that where a tortious act is particularly egregious and the societal interest in deterring similar conduct in the future is great, punitive damages may be justified. ${ }^{81}$ In order to promote the societal interest in deterrence in these particular cases, however, an action would have to be maintainable outside the scope of the essentially compensatory workers' coinpensation system.

Although the section 4553 award is a penalty, despite the court's characterization, ${ }^{82}$ and therefore has, at least theoretically, a deterrence value, the impact of the penalty is limited by a $\$ 10,000$ ceiling. Given this ceiling, the employer can calculate whether it is inore economical to risk paying a fixed penalty rather than to shore up an operation that would otherwise mdicate a reckless disregard for the safety of the workers. ${ }^{83}$ If deterrence is limited to the statutory penalty, it would be effective only insofar as it tips the employer's cost and earnings calculus. Thus, in order to effectively deter egregious conduct, the injured employee must be able to seek a remedy in tort, subject to general and punitive damages. This places the power to deter in a jury, representimg society, rather than in the employer's accountant.

The Johns-Manville Products court was hesitant to allow such actions at law, for fear that they would undermine the premise of workers' coinpensation. ${ }^{84}$ That premise is an imphit, reciprocal agreement between the employee and the employer. Swift compensation is guaranteed in exchange for employer immumity. Yet nowhere does this tradeoff reflect the interests of future workers. It is largely their interests in a safe workplace that are protected by the availability of a punitive damage award. ${ }^{85}$ By allowing a tort remedy in special cases calling for deterrence measures, the court recognized the limits of the system and sought to protect those interests that the system does not directly safeguard. ${ }^{86}$

$\S 21]$ and if it has no other sanction, it is beyond the legislative power and void." Id. at $192,193 \mathrm{P}$. at 110 .

81. 27 Cal. 3d at 478,612 P.2d at 956,165 Cal. Rptr. at 866 .

82. The notion of a penalty is reinforced by the statutory prohibition against the employer insuring against this award. See CAL. INs. CODE $§ 11661$ (West 1972).

83. See generally J. McCarthy, Punitive Damages in Bad Faith Cases $\S 1.34$ (2d ed. 1978); J. RAwLS, A THEORY OF Justice 472-85 (1971) (discussing the principles of inorality).

84. 27 Cal. 3d at 474,612 P.2d at 953,165 Cal. Rptr. at 863.

85. Deterrence cannot be handled as well through criminal law, as suggested by Azevedo v. Industrial Aceident Comm'n, 243 Cal. App. 2d 370, 373-74, 52 Cal. Rptr. 283, 285 (3d Dist. 1966); the state would have less incentive to enforce, and a more difficult standard of proof would protect the defendant in a criminal proceeding.

86. The Johns-Manville Products majority expressed concern that generally allowing intentional injuries to be actionable in tort would cause a sudden severe stress to be placed on the judicial system through an increase in cases brought into superior court. 27 Cal. 3d at 478, 612 P.2d at 956,165 Cal. Rptr. at 866 . However, such fears are purely speculative. In fact, the most sound imdication that can be drawn presently from the experience of other states that allow tort 
The dissent in Johns-Manville Products expressed its fear that the availability of punitive damages for intentional employer misconduct causing worker injuries would end employer-sponsored medical examination programs such as the one run by the defendant. ${ }^{87}$ This conclusion overlooks the fact that liability is predicated only on intentional einployer misconduct and not on the quahty of the examination program. The Johns-Manville Products holding in effect only forces the employer to disclose to the einployee the medical information that he has contracted a work-related disease. The costs to the employer of such disclosure are probably minimal compared to the potential habil-

actions for intentional employer misconduct is that relatively few cases actually emerge on the issue. See note 38 supra.

For valid claims, it is difficult to justify retaining workers' compensation exclusivity for intentional employer misconduct merely because more judicial cases may result. The compensation process admittedly saves time and expense for the parties involved, but precluding tort remedies would virtually eliminate the opportunity to deter socially intolerable einployer conduct.

The court's anxiety about those cases where employees merely gainble on a large tort recovery is somewhat more legitimate. Yet instances of employee abuse of the tort alternative will not easily reach the jury, which is sometimes portrayed as overly sympathetic to injured plaintiffs. One major procedural obstacle for frivolous tort plaintiffs is the control of the judge over the pleadings. If an employee-plaintiff does not state facts sufficient to state an intentional cause of action, the judge can dismiss the suit on defendant's demurrer. CAL. Civ. Proc. Code \$ 581 (West 1976). This means that the plaintiff must allege substantial certainty of employee injury, if not purposeful employer misconduct. Furthermore, even if plaintiff has the opportunity in discovcry to search for evidence of employer knowledge of certain workplace dangers, the defendant may, after 60 days from the date the action was filed, inove for summary judgment if no triable issue of material fact on intentional employer misconduct has been raised. CAL. Civ. Proc. Code $\$ 437 \mathrm{c}$ (West Supp. 1981). If the motion is granted, a lengtlyy and expensive jury trial can be averted.

Perhaps a more powerful disincentive to nonserious tort plaintiffs would be the long delay that they would face before they could collect even a compensation award. California decisions regarding einployer assault have stressed that California does not have a truly elective system of remedies. Azevedo v. Abel, 264 Cal. App. 2d 451, 455, 70 Cal. Rptr. 710, 712 (3d Dist. 1968); Carter v. Superior Court, 142 Cal. App. 2d 350, 355, 298 P.2d 598, 601 (2d Dist. 1956). Plaintiff essentially has only a choice about the initial forum. He can even file both a compensation and a tort claim simultaneously. Once a compensation award has been made, however, all tort claims are precluded on that cause of action. Unruh v. Truck Ins. Exch., 7 Cal. 3d 616, 498 P.2d 1063, 102 Cal. Rptr. 815 (1972), miglt lead one to beheve that the plaintiff in Johns-Manville Products could successfully surmount this barrier by sphitting the causes of action distinctly into those purely compensable and those actionable in tort. In this manner, the plaintiff would be able to collect at least some payment to tide him over in the short run while pursuing the potentially lucrative tort action. However, Unruh stressed that its anomalous outcome, in which the plaintiff could recover punitive damages in tort even after she had been coinpensated, was attributable primarily to the fact that it was the insurer only, and not the employer, being sued in tort. 7 Cal. 3d at 634,498 P.2d at 1076, 102 Cal. Rptr. at 828 . Hence, a court in the more typical JolmsManville Products situation would probably refuse to allow such split clains to be pursued independently against an employer-defendant.

87. 27 Cal. 3d at 480-81, 612 P.2d at 957, 165 Cal. Rptr. at 867 (Clark, J., dissenting). Ironically, this argues in favor of permitting both aspects of the concealment to escape workers' compensation exclusivity. If the mitial concealment of the asbestos danger were actionable as well, the employer who knew and intentionally covered up the hazardous nature of the workplace environment would be liable whether he provided a medical exammation program or not. 
ity costs of intentionally withholding the information. ${ }^{88}$ If one assumes that most employers intend to act in good faith, it is unlikely that the Johns-Manville Products holding threatens to curtail inedical exainination programs sponsored by the employer.

\section{B. Separation of Injuries}

The two pleaded causes of action at issue in Johns-Manville Prod$u c t s$ were similar, both involving misrepresentations and concealments on the part of the employer. The court, however, accorded thein different legal treatment. ${ }^{89}$ The concealment of the hazards of the industrial environment and the misrepresentations as to its safety were held to have resulted in a work-related injury. ${ }^{90}$ According to the court, this initial injury was subject to the exclusivity rule of the statute and could be remedied only by a compensation award. The concealment of information obtamed through the employer-sponsored inedical examination, however, was held to have aggravated the previous injury and was accordingly held actionable at law.

In making this distinction, the court misapplied the very standards it set for allowing an action at law; both concealments can be fairly categorized as intentional misconduct consisting of an aggravation of a work-related injury. Moreover, this distinction is not supported by the substantial certainty rationale, the objective expectation rationale, or policy considerations.

The concealment of the workplace hazards, which led to what the

88. It is conceivable that the total costs of disclosing the medical information could outweigh the risk of incurring a tort judgment, particularly in cases such as Johns-Manville Products where the employer may be forced to make a large capital expenditure in order to make sure the workplace meets federal and state health regulations. Disclosure might cause employees to resign in large numbers, or cause them to demand that their collective bargaining agent seek employerprovided safety equipment.

Even in a worst case scenario, however, it is unlikely that the employer would feel completely free to drop the medical programs, particularly if such programs are part of a collective bargaining agreement. If nothing else, many of the potential costs attributable to the disclosure would provide the employer with various tax deductions, which would have to be factored into the employer's calculus. Moreover, if, as this Note argues, see notes 94-99 and accompanying text infra, employers were liable for all intentional concealments of workplace hazards that are substantially certain to cause employee injury, it would be pointless for the employer to do away with the medical programs, since it would still be liable for not disclosing the hazard initially.

89. The Cahifornia Supreme Court was the first-body to suggest separate treatment of the two counts of concealment. Neitlier the lower courts nor the briefs of the two sides made such a distinction. See Amicus and Party Briefs (on file at California Law Review). The court seems to have been unduly concerned with conducting a balancing act, allowing a tort remedy in some cases, while avoiding a Pandora's box. $27 \mathrm{Cal}$. 3d at 478, 612 P.2d at 956, 165 Cal. Rptr. at 866. Regarding the first concealment, the court was concerned that "if an action at law were allowed as a remedy, many cases cognizable under workers' compensation would also be prosecuted outside the system." Id. at 474,612 P.2d at 953,165 Cal. Rptr. at 863.

90. 27 Cal. 3 d at $474-75,612$ P.2d at 954,165 Cal. Rptr. at 864. 
court classified as a "first instance" injury," in fact also announted to an aggravating injury, and should have been categorized as such. ${ }^{92}$ Factors contributing to the degeneration of lung tissue included the einployer's alleged concealment from the einployee of information regarding the environinental hazards of the workplace and its inisrepresentation of the workplace as safe. These factors induced the employee to remain in the unsafe environment. Environinental carcinogens in the workplace are a cause of pulmonary disease; inducing the deceived employee to remain at the workplace prolonged exposure to such substances and served to aggravate the disease. Accordingly, the first instance concealment should be actionable in tort, as it too amounts to an aggravation, ${ }^{93}$ as well as an initial cause.

This Note has argued that the standard of aggravation is acceptable because it utilizes a threshhold of substantial certainty of injury in order for intentional employer misconduct to be actionable. In light of this standard, the court's disparate treatment of the two concealments of information is unfounded. ${ }^{94}$ Both causes of action involved the element of intentional employer misconduct. The second concealment adinittedly imvolved a higher degree of certainty of injury than did the

91. Id. at 474, 612 P.2d at 954, $165 \mathrm{Cal}$. Rptr. at 863 .

92. The plaintiff suffered initial lung damage, according to the allegations, by virtue of the employer's "deliberate failure to assure that the physical environment of the workplace [was] safe." Id. at 474, 612 P.2d at 953, 165 Cal. Rptr. at 863 . By keeping the asbestos dust concentrations above the levels permitted by federal and state regulations, the employer hastened the onset of the initial injury. The court was correct, however, in holding that injuries resulting from an employer's failure in diligence only, without some other complicating factor, are remediable exclusively under workers' compensation. Id. at $472 \mathrm{n} .6,612 \mathrm{P.2d}$ at $952 \mathrm{n} .6,165 \mathrm{Cal}$. Rptr. at 862 n.6. However, the court itself seemed confused as to what the employce really was alleging in his complaint. He was not alleging that the employer's failure was merely a failure to take precautions, but rather that it failed to take precautions and then intentionally concealed the fact that there was a hidden danger in the workplace.

93. Moreover, as a factual matter, the two concealments became multiple facets of one continuous injury. The concealments were really one single course of employer action, with two necessary parts. The interdependency worked both ways, since the workplace concealment would have been exposed much sooner had the intentional medical cover-up not followed. Yet, for all the interdependence of two acts of concealment, if there had been no medical examination, and hcnce no second concealment, the ultimate injury caused by the first concealment would have been identical to that engendered by the combined concealments, assuming that it had been allowed to progress as long. Indeed, the court alluded to the difficulty of separation in cases of multiple acts resulting in one injury. See id. at $477 \mathrm{n} .11,612$ P.2d at $956 \mathrm{n} .11,165 \mathrm{Cal}$. Rptr. at 865 n.11.

94. The substantial certainty standard could be applied to the Johns-Manville Products situation in two ways, since there was a substantial certainty of initial injury as well as a substantial certainty of aggravation of injury. The argument made in the text accompanying notes 96-99 infra addresses the former application, i.e., that the employer knew to a substantial certainty that his intentional concealment and misrepresentation of the workplace hazards would result in injury to one of the employees. This argument should not be confused with the argument, rejected by the courts, that the employer should be hable in tort when it fails to take measures to ensure the safety of the workplace as a general matter. See note 92 supra. 
first, since almost any serious illness will inevitably becoine worse if concealment of information precludes the most effective medical treatment. In addition, the employer was alleged to have been aware of the hazardous qualities of asbestos, ${ }^{95}$ thereby corroborating the certainty of injury inherent in such concealment.

However, the initial concealment of the asbestos workplace hazard also meets the substantial certainty standard. Of course, the employer arguably could not have been substantially certain that a particular employee would be injured, even though that employee was sent to work daily in an environment known to have a dangerous asbestos concentration level. Epidemiological statistics indicate that the probability of serious illness for a given individual becoines greater over time, but will never approach one hundred percent. ${ }^{96}$ However, if one looks at the entire group of employees who were knowingly ordered to work in the dangerous environment, the probability that at least one worker would become seriously ill does approach one hundred percent. ${ }^{97}$ Thus, the worker's injury resulted froin einployer inisconduct that was intentionally injurious because it consisted of (1) a purposeful concealment in order to induce continued employinent, and (2) knowledge of a collective risk approaching a virtual certainty that some serious employee injury would occur in the workplace. Because of the high degree of certainty that at least one member of the class of employees would contract an asbestos-related disease, an intent to injure inay be inferred ${ }^{98}$ from the initial concealment of the workplace hazard that is

95. 27 Cal. 3d at 469, 612 P.2d at 950,165 Cal. Rptr. at 860 .

96. For a variety of studies, see S. EpsteIn, The Politics of CANCER 81-86 (1979). It is crucial to realize, however, that the statistics refer only to very serious manifestations of the diseases that can be attributed largely to the asbestos exposure. No minimal level has yet been determined as being coinpletely safe.

97. A National Cancer Institute and National Institute of Environmental Health Sciences study states that the "total fraction of heavily exposed [asbestos] workers likely to die of . . . cancers is probably between 35-44 percent." National Cancer Institute and National Institute of Environmental Health Sciences, Estimates of the Fraction of Cancer Incidence in the United States Attributable to Occupational Factors (Draft Summary) (1978), cited in Brief of Amici Curiae, Kent D. Wise, M.D., at 9 (on file at California Law Review). Thus, in a workplace where there is heavy exposure, the chances are that for every three workers, one worker will attract a fatal asbestos-related disease. These statistics are evidence of what can only be characterized as a substantial certainty of injury or death. They do not, however, bear directly on the Johns-Manville Products case discussed in this Note, for there is no indication that the workplace was one of "heavy exposure." See generally Karjala v. Johns-Manville Prods. Corp., 523 F.2d 155 (8th Cir. 1975) (asbestosis as a continuing tort); Borel v. Fibreboard Paper Corp., 493 F.2d 1076 (5th Cir. 1972), cert. denied, 419 U.S. 830 (1974).

98. Dean Prosser cites the example of the man who fires a bullet into a dense crowd. Though he may hope that no one will be injured, his knowledge of the inevitability of the consequences to at least one crowd member is the basis for a finding of intent. W. Prosser, supra note $30, \S 8$, at 32 . Similarly, the industrial employer surely does not want to injure any member of his or her work force. However, by inducing the employee's continued exposure to asbestos, the likelihood that at least one worker will be injured approaches substantial certainty. 
no different from that imferred from the subsequent concealment of the medical records.

This argument is, of course, subject to limitations. Many work environments have some degree of danger attached to them, so that under a substantial certainty standard practically anyone who is injured in such workplaces could raise an intentional tort claim. The dilemma is best illustrated by the example of a dangerous but socially useful activity, not unlike the manufacture of asbestos, such as the building of long suspension bridges. An employer can be substantially certain that some worker will die even if the most elaborate precautions that the employer can afford are taken. Still, society does not hold the employer liable for intentional mjuries when workers do die. Even if inadequate precautions were taken by the einployer, workers' compensation would remain the exclusive remedy. ${ }^{99}$ It is only when the employer conceals the hidden risks involved for the bridge construction worker that the court goes beyond exclusive compensation. Substantial certainty, then, leads to employer tort habihty only when such certainty can be demonstrated and the employer intentionally conceals or misrepresents the risk to its employees.

The objective expectation rationale ${ }^{100}$ put forth in Magliulo and cited in Johns-Manville Products also supports treating the two injuries similarly. It is as apphicable to the fraudulent concealment of environmental hazards as it is to the concealment of medical information, since both acts arguably fall into the interstitial category of "intentional" misconduct. The court reinforced its holding by noting that employees neither contemplate intentional concealment of medical data, nor suspect that they might relmquish their rights to remedy in tort. ${ }^{101}$ However, the court beheved that employees may anticipate the employer concealing the hazards of the workplace ${ }^{102}$ and suggested that employees might be willing to surrender their rights of action for this "ordinary type of work-related"103 injury.

The court thus suggested that if employer misconduct can be anticipated, it becomes an ordmary workplace risk and thus subject exclusively to workers' compensation remedies. The court, however, failed to explam why the first concealment was any more expected than the second concealinent. Simce both involve employer deceit, it is unclear why the employee would expect bad faith on the part of the employer in one instance but not the other.

99. See notes 92,94 , and accompanying text supra.

100. See notes 57-69 and accompanying text supra.

101. $27 \mathrm{Cal}$. 3d at 477, 612 P.2d at 955-56, 165 Cal. Rptr. 865.

102. Id.

103. Id. 
The distinction between an einployee's capacity to anticipate the concealment of workplace hazards and his capacity to anticipate the concealment of personal medical information must rest on the presuinption that the employee can detect environmental hazards on his own. This presumption is realistic where the hazard is apparent; for example, where there is an oil spill on the factory floor. It is also appropriate where the employee may reasonably anticipate that a workplace chemical is toxic, as in the manufacture of pesticides. ${ }^{104}$

Asbestos in the workplace environment presents a different situation. First, its dangers are not readily apparent. Its lethal effects becoine manifest only after a long period of time. Moreover, the dangers of asbestos have only recently becoine public knowledge. While the coinpany allegedly knew of the hazards of asbestos in $1924,{ }^{105}$ case studies of asbestosis in workers did not begin until the 1950's, ${ }^{106}$ and necessarily have been long-term matters. It was not until 1972 that OSHA began hearings to reduce permissible asbestos levels. ${ }^{107}$ Plaintiff Rudkin worked for Johns-Manville froin 1946 to $1975 .{ }^{108}$ Durmg this time period, the asbestos industry had an effective nonopoly over information as to asbestos related diseases. ${ }^{109}$ When the plaimtiff inquired as to the ambient dangers of the workplace, the employer knowingly misrepresented the factory as safe. The plaintiff could not realistically inform himself through other channels. Unless plaimtiff was supposed to anticipate employer bad faith, he could not reasonably be expected to anticipate that the workplace was anything but what it was represented to be. He would have no reason to know that every day on the job increased his cliances for injury, nor would he know that remaining at the workplace would aggravate a developing injury.

Actually, it would seem that employees are better able to discover concealment of personal medical information, even if they cannot anticipate it, simply because they can always consult coinpetent physicians who sliould be able to inform them that they liave been deceived by the employer as to the state of their health. Prior to that point, however, the einployee would have no way of knowing that the workplace itself posed health hazards. If the second concealment is actionable because it is difficult to discover, then the first concealment and misrepresentation should be equally, if not more, actionable. ${ }^{110}$

104. See Wright v. FMC Corp., 81 Cal. App. 3d 777, 146 Cal. Rptr. 740 (1st Dist. 1978); note 44 and accompanying text supra.

105. 27 Cal. 3d at 469,612 P.2d at 950,165 Cal. Rptr. at 860 .

106. See S. EPSTEIN, supra note 96 , at 80-81.

107. Id. at 83 .

108. 27 Cal. 3d at 469,612 P.2d at 950,165 Cal. Rptr. at 860 .

109. S. EPSTEIN, supra note 96 , at 102.

110. It is interesting to note that the plaintiff joined as defendants two doctors who had 
Because the environmental misrepresentation was as unanticipated as that of the medical data, the employer's misconduct cannot reasonably be characterized as an ordinary workplace risk. Accordingly, under the objective expectation rationale, the employee no more expects to relinquish his common law rights for this extraordinary, unanticipated injury than he does for the injury resulting from the unanticipated cover-up of his medical records.

Finally, the policy considerations that allow egregious employer misconduct to be actionable in tort are applicable to both causes of action. Assuming that the potential for sizable general and punitive damage claims constitutes a significant deterrent to socially intolerable employer conduct, there should be no significant difference between the way the injuries from the first and second concealments are handled by the judicial system. Both are intentional frauds perpetrated against the worker and both should be deterred. ${ }^{111}$

Given the alleged facts in Johns-Manville Products, the injuries are equally reprehensible. The inajority provided no good reason why society should allow punitive damages to be sought against an employer who fraudulently conceals inforination vital for proper medical treatment of someone who is alrcady ill, but not against an employer who conceals information about hazardous working conditions while sending workers into an environment in which injury to at least some workers is a virtual certainty. A rational system of compensation and damages should not take notice of medical concealment that harms a single employee directly yet remain indifferent to the needs of the class from which the individual victim comes simply because the entire class does not manifest an injury. ${ }^{12}$ The lack of directness or personal dignity in the latter case does not make the need to deter egregious conduct less compelling.

treated him. The complaint alleged that they were unqualified. See $27 \mathrm{Cal}$. 3d at $469 \& \mathrm{n} .2,612$ P.2d at 950 \& n.2, 165 Cal. Rptr. at 860 \& n.2. The plaintiff may have felt that the severity of his illness was due in part to factors other than the employer's concealments, i.e., the physicians' inability to deduce that the illness was work-related. Had the doctors been qualified, it seems probable that the employer's second concealment would have been exposed. It is possible that the initial concealment of the workplace hazard itself would also have been exposed, but only after an accurate diagnosis had pierced the second concealment.

111. See W. Prosser, supra note $30, \S 2$, at 9 . Intentional acts can be more easily deterred than negligent ones, since conscious decision and action are involved.

112. This is one of the important contributions of the substantial certamty aspect of tort law dealing with intentional conduct. It does not require the motive of the defendant to be discerned, as does the purposeful standard; it is more result-oriented, as long as the defendant knows the result. See W. Prosser, supra note 30, §8, at 31-32. For a more philosophical outlook, see J. RAwLS, supra note 83 , at $472-85$. 


\section{CONCLUSION}

The Johns-Manville Products decision settled the question in California as to whether all injuries that occur within the course of employment are to be remedied solely by workers' compensation. Tle court stated that in instances where an employer deliberately acts with the purpose to mjure an employee, or where his act results in an aggravation of a previous work-related injury, then the employee can maintain an action at law and has the opportunity to collect general and punitive damages. In creating tlie aggravation exception, the court established an exception to the exclusivity rule that is broader than any previously advanced by a California appellate court. Although the exception appears to be narrowly drawn, the analytical rationale relied upon by the court (Magliulo's look to reasonable employee expectations), the substantial certainty rationale offered in this Note, and the policy of deterrence all suggest that more types of intentional employer misconduct other than aggravation of previous injuries should be actionable at law.

Thomas L. Riordan*

* B.A. 1979, Yale University; third-year student, Boalt Hall School of Law, University of California, Berkeley. 